\title{
Effects of Photoperiod and Glucose-Supplemented Drinking Water on the Performance of Dairy Calves
}

\author{
V. R. Osborne, ${ }^{* 1}$ N. E. Odongo, ${ }^{*}$ A. M. Edwards, $†$ and B. W. McBride ${ }^{\star}$ \\ *Department of Animal and Poultry Science, and \\ †Computing and Communications Services, University of Guelph, Guelph, Ontario, Canada N1G 2W1
}

\begin{abstract}
Long-day photoperiods (LDPP) have been shown to increase milk production in lactating dairy cattle. The objective of this study was to determine the effects of supplemental light and glucose-supplemented drinking water on starter dry matter intake (DMI), water intake, serum and rumen metabolites, and growth performance of calves from birth to $8 \mathrm{wk}$ of age. The experiment was conducted as a completely randomized design with a 2 $\times 2$ factorial arrangement of treatments. The calves were assigned at birth to 1 of 4 treatments: 1) $10 \mathrm{~h}$ of light, $14 \mathrm{~h}$ of dark (short-day photoperiods; SDPP), ad libitum intake of water, and no glucose supplementation; 2) $10 \mathrm{~h}$ of light, $14 \mathrm{~h}$ of dark, and ad libitum intake of water supplemented with $50 \mathrm{~g}$ of glucose/L; 3) $18 \mathrm{~h}$ of light, $6 \mathrm{~h}$ of dark (LDPP), and ad libitum intake of water, and no glucose supplementation; and 4) $18 \mathrm{~h}$ of light, $6 \mathrm{~h}$ of dark, and ad libitum intake of water supplemented with $50 \mathrm{~g}$ of glucose/L. Fluorescent lights were used to provide lighting at an intensity of approximately $600 \mathrm{~lx}$ at the eye level of calves. The calves were bucket-fed $2 \mathrm{~L}$ of whole milk offered twice daily at 0700 and $1600 \mathrm{~h}$ and had a free access to a textured calf starter. The calves on LDPP were heavier at $d 56$ than SDPP calves regardless of level of glucose supplementation. The average daily gain of the calves on LDPP from d 29 to 42 and from d 43 to 56 was greater than for SDPP calves regardless of the level of glucose supplementation. The greater average daily gain of LDPP calves from d 29 to 56 coincided with the greater calf starter DMI of these calves. Body widths through hooks were highly $(r=0.72)$ correlated with body weights, which in turn were related to calf starter DMI. Calves on LDPP had greater ruminal osmolarity and greater concentrations of acetate, propionate, butyrate, and total volatile fatty acids than SDPP calves regardless of the level of glucose supplementation. Calves on LDPP
\end{abstract}

Received May 31, 2007.

Accepted July 31, 2007.

${ }^{1}$ Corresponding author: vosborne@uoguelph.ca had lower Ca:P ratio than the SDPP calves regardless of level of glucose supplementation. The concentrations of serum glucose and sodium for the glucose-supplemented calves were greater than for nonsupplemented calves regardless of lighting regimen. These results suggest that LDPP encouraged greater consumption of calf starter, which stimulated faster rumen development in the LDPP calves as evidenced by greater volatile fatty acid concentrations.

Key words: photoperiod, drinking water, glucose supplementation, dairy calf

\section{INTRODUCTION}

Long-day photoperiod (LDPP; 16 to $18 \mathrm{~h}$ of light) is galactopoietic in dairy cows (Dahl et al., 2000). Supplemental lighting (16 to $18 \mathrm{~h}$ of light) during lactation has been shown to increase milk yield in dairy cattle (Evans and Hacker, 1989; Dahl et al., 1997, 2000) and stimulate BW gain in heifers (Tucker et al., 1984). Heifers (84 $\pm 15 \mathrm{~d}$ of age) exposed to LDPP had greater growth and an earlier onset of puberty compared with heifers exposed to short-day photoperiod (SDPP; $8 \mathrm{~h}$ of light, $16 \mathrm{~h}$ of dark; Rius et al., 2005). Long-day photoperiod has been shown to promote mammary parenchymal growth before and after puberty (Petitclerc et al., 1985). Rius and Dahl (2006) showed that LDPP exposure during the prepubertal growth phase resulted in greater milk secretion during the first lactation. Photoperiod manipulation therefore offers a management tool that could enhance growth and accelerate the onset of puberty (Hansen et al., 1983; Petitclerc et al., 1983; Schillo et al., 1992) and therefore reduce the age of heifers at first parturition (Peters et al., 1980; Schillo et al., 1983). However, there is little information on the effects of LDPP on growth performance in neonatal calves.

Water is an important nutrient in dairy production (Houpt, 1984; Murphy, 1992). Too often, it is assumed that if a calf is being fed a liquid diet, its needs for water will be satisfied (NRC, 2001). However, fresh water in addition to water consumed as part of the diet, is critical for optimal growth and consumption of dry 
feed (Leaver and Yarrow, 1972; Kertz et al., 1984). Water constitutes 70 to $75 \%$ of the weight of the calf and plays important roles as a solvent for nutrients, a thermoregulator, and an osmoregulator (Davis and Drackley, 1998). Osborne et al. (2002) showed that glucose supplementation in the drinking water of transition cows improved the nitrogen status of the cow by reducing the rumen ammonia levels and blood urea. Additionally, Thomas et al. (2007) showed that flavoring agents need not be added only to the starter feed for calves, but also that flavor can stimulate DMI and BW gain when used in drinking water.

The primary stimulus for the development of ruminal epithelia in calves is controlled by the VFA propionate and butyrate (Flatt et al., 1958; Sander et al., 1959; Quigley et al., 1997). Waldo and Schultz (1960) showed that sucrose moderately increased in vivo butyrate production in steers. The role of rumen development and the process of transitioning calves from their neonatal reliance on nutrients supplied by milk to nutrients supplied in solid feed is therefore of substantial economic importance to producers. Additionally, adding sucrose to the diet of dairy cattle in early lactation increased DMI (Nombekela et al., 1994). It was hypothesized that supplementation of "sugar water" in calf's drinking water would stimulate calf starter intake and accentuate the production of propionate and butyrate in the rumen and therefore accelerate rumen development. The objective of this study was to determine the effects of supplemental light and glucose-supplemented drinking water on starter DMI, water intake, serum and rumen metabolites, and growth performance of calves from birth to 8 wk of age.

\section{MATERIALS AND METHODS}

\section{Animals and Experimental Design}

Twenty-four female Holstein dairy calves (initial BW of $42.2 \pm 3.8 \mathrm{~kg}$, mean $\pm \mathrm{SD}$ ) housed in an insulated nursery (room temperature, $20^{\circ} \mathrm{C}$ ) at the Elora Dairy Research Centre, University of Guelph (Guelph, Ontario, Canada), were used in the study. Animals were cared for and handled in accordance with the Canadian Council on Animal Care regulations, and the University of Guelph Animal Care Committee reviewed and approved the experiment and all procedures carried out in the study. Calves were separated from dams at birth and placed in individual $1.2-\times 1.5-\mathrm{m}$ pens bedded with kiln-dried wood shavings. The calves were fed $2 \mathrm{~L}$ of pooled colostrum within 90 min of birth, a second $2 \mathrm{~L}$ of colostrum 8 to $12 \mathrm{~h}$ after the first colostrum feeding, and whole milk thereafter.

The study was conducted as a completely randomized design with a $2 \times 2$ factorial arrangement of treatments
Table 1. Nutrient composition of textured calf starter

\begin{tabular}{|c|c|}
\hline Nutrient & $\%, \mathrm{DM}$ \\
\hline DM, \% & 85.4 \\
\hline $\mathrm{CP}, \%$ & 18.0 \\
\hline $\mathrm{ADF}, \%$ & 7.5 \\
\hline $\mathrm{NDF}, \%$ & 22.8 \\
\hline $\mathrm{Ca}, \%$ & 1.13 \\
\hline $\mathrm{P}, \%$ & 0.69 \\
\hline $\mathrm{K}, \%$ & 1.13 \\
\hline $\mathrm{Mg}, \%$ & 0.28 \\
\hline $\mathrm{Na}, \%$ & 0.35 \\
\hline Vitamin A, IU/kg & 12,500 \\
\hline Vitamin D, IU/kg & 5,000 \\
\hline Vitamin E, IU/kg & 45 \\
\hline $\mathrm{NE}_{\mathrm{M}},{ }^{1} \mathrm{Mcal} / \mathrm{kg}$ & 2.45 \\
\hline $\mathrm{NE}_{\mathrm{G}},{ }^{1} \mathrm{Mcal} / \mathrm{kg}$ & 1.72 \\
\hline
\end{tabular}

${ }^{1}$ Calculated using NRC (2001).

from June 23 to September 8, 1999. The calves were assigned at birth to 1 of 4 treatments: 1) $10 \mathrm{~h}$ of light, $14 \mathrm{~h}$ of dark (SDPP), ad libitum intake of water, and no glucose supplementation; 2) $10 \mathrm{~h}$ of light, $14 \mathrm{~h}$ of dark, and ad libitum intake of water supplemented with $50 \mathrm{~g}$ of glucose/L; 3) $18 \mathrm{~h}$ of light, $6 \mathrm{~h}$ of dark (LDPP), and ad libitum intake of water, and no glucose supplementation; and 4) $18 \mathrm{~h}$ of light, $6 \mathrm{~h}$ of dark, and ad libitum intake of water supplemented with $50 \mathrm{~g}$ of glucose/L. Fluorescent lights were used to provide lighting at an intensity of approximately $600 \mathrm{~lx}$ at the eye level of calves to simulate the lighting outside. The calves were bucket-fed $2 \mathrm{~L}$ of whole milk offered twice daily at 0700 and $1600 \mathrm{~h}$ and had free access to a standard textured calf starter (Rumax 20\% calf starter, Floradale Feed Mill Limited, Floradale, Ontario, Canada) throughout the study. Starter orts were collected and weighed daily. Milk, water, and starter intakes were recorded daily. The chemical analysis of the calf starter is presented in Table 1 . The trial lasted from birth to 8 wh of age.

Calves were weighed and measured for withers height, hip height, hip width, and heart girth at birth, d 28, and d 56. Calves were weighed on a platform scale (Salter Scales, Fairfield, NJ). Wither and hip heights were measured using a sliding-scale height stick with a bubble level. Heart girths were measured using a Nasco Holstein dairy heart girth tape (Nasco, Fort Atkinson, WI) and hip width with a hipometer caliper (Dairy Innovations, Alexander, NY). With the heart girth tape method, the tape was placed around the heart girth of the animal and pulled taut. The measurement was read directly off the tape according to the circumference of the animal. With the hipometer, the forcepslike arms were cupped over the greater trochanters of the left and right femurs of the heifer. The measurement was then recorded according to the width of the 
opening of the caliper arms by reading directly from the sliding scale of the hipometer (Skidmore, 2001).

Blood samples were obtained at birth and weekly thereafter on $\mathrm{d} 7,14,28,35,42,49$, and 56 by venipuncture of the jugular vein before the morning feeding into evacuated $10-\mathrm{mL}$ sterile serum test tubes (Vacutainer, Becton Dickinson, Rutherford, NJ). Samples were allowed to stand at room temperature for $30 \mathrm{~min}$ and then centrifuged at $2,000 \times g$ for $15 \mathrm{~min}$ in a refrigerated centrifuge (model TJ-6, Beckman, Palo Alto, CA) at $4^{\circ} \mathrm{C}$. Serum was separated and transferred to $7-\mathrm{mL}$ plastic scintillation vials and stored at $-70^{\circ} \mathrm{C}$ until analysis.

Rumen fluid was aspirated $4 \mathrm{~h}$ postfeeding on d 28, 35,42 , and 56 using a Geishauser oral probe (Geishauser, 1993). A $200-\mathrm{mL}$ sample of the rumen fluid was extracted and a subsample was filtered and the $\mathrm{pH}$ measured immediately using a Fisher Accumeter pH meter (model 610, Fisher Scientific, Hampton, NH) calibrated using $\mathrm{pH} 4.0$ and $\mathrm{pH} 7.0$ buffer solutions (Fisher Scientific). A subsample of the rumen fluid was transferred to a 50-mL disposable sterile centrifuge tube (Fisherbrand, Ottawa, Ontario, Canada) and frozen at $-70^{\circ} \mathrm{C}$ for further analysis.

\section{Chemical Analysis}

Samples of the calf starter were obtained from each bag when the bags were opened and composited monthly. Analytical DM content of the starter was determined by oven drying at $135^{\circ} \mathrm{C}$ for $2 \mathrm{~h}$ (method 3.002; AOAC, 1990), and OM was determined by ashing at $500^{\circ} \mathrm{C}$ for $16 \mathrm{~h}$ (method 942.05; AOAC, 1990). The CP contents were determined using a Leco FP 428 nitrogen analyzer (Leco Corporation, St. Joseph, MI; method 4.2.08; AOAC, 1990). The calf starter samples were also analyzed for ADF (method 973.18c; AOAC, 1990) and NDF (Van Soest et al., 1991) using $\alpha$-amylase (no. A3306, Sigma Chemical Co., St. Louis, MO) and sodium sulfite corrected for ash concentration adapted for an Ankom 200 fiber analyzer (Ankom Technology, Fairport, NY). Calcium, phosphorus, potassium, magnesium, and sodium were analyzed by inductively coupled plasma spectroscopy (method 945.46; AOAC 1990).

The serum was analyzed for electrolytes $(\mathrm{Ca}, \mathrm{P}, \mathrm{Mg}$, $\mathrm{Na}, \mathrm{K}$, and chloride), total protein, urea, glucose, and osmolarity. The concentration of BHBA in serum was determined using the Sigma Diagnostics enzymatic method (kit 310-A, Sigma, St. Louis, MO) following the methods of Williamson et al. (1962), and NEFA concentrations were determined using a colorimetric assay (NEFA-C kit, Wako Chemicals, Richmond, VA), following modifications by Johnson and Peters (1993). Blood biochemistry was evaluated using a Boehringer Mann-
heim/Hitachi 911 analyzer at the Laboratory Services Division, University of Guelph, Ontario, Canada.

Rumen fluid samples were thawed and centrifuged at $2,200 \times g$ for $20 \mathrm{~min}$ in a refrigerated $\left(4^{\circ} \mathrm{C}\right)$ centrifuge as above. Rumen VFA concentrations were determined on a Varian GC3400 gas chromatograph (Varian Canada, Mississauga, Ontario, Canada) using a fused-silica capillary column $(1.5 \mathrm{~m} \times 0.53 \mathrm{~mm}$ i.d.; Nukol, Supelco Canada Ltd., Mississauga, Ontario, Canada). The injection and flame-ionization detector temperatures were $200^{\circ} \mathrm{C}$, and the carrier gas was helium. The isothermal column temperature was $85^{\circ} \mathrm{C}$ with a hold time of 10 min. Lactic acid concentration in rumen samples was analyzed using the colorimetric method of Taylor (1996). Rumen ammonia nitrogen $\left(\mathrm{NH}_{3} \mathrm{~N}\right)$ concentration in the rumen fluid was determined using the indophenol-blue colorimetric procedure of Novozamski et al. (1974).

\section{Statistical Analysis}

The ANOVA for weight gain, ADG, water intake, calf starter DMI, serum and rumen variables, and structural body measurements was conducted using the MIXED procedure of SAS (v. 9.1, SAS Inst. Inc., Cary, $\mathrm{NC}$ ), using the model $\mathrm{Y}_{\mathrm{ij}}=\mu+\alpha_{\mathrm{i}}+\beta_{\mathrm{j}}+\alpha \beta_{\mathrm{ij}}+\varepsilon_{\mathrm{ij}}$, where $\mathrm{Y}_{\mathrm{ij}}$ is the dependent variable, $\mu$ is the overall mean, $\alpha_{\mathrm{i}}$ is the effect of light $(i=1,2), \beta_{j}$ is the effect of glucose supplementation $(\mathrm{j}=1,2), \alpha \beta_{\mathrm{ij}}$ is the effect of a light $\times$ glucose supplementation interaction $\left({ }_{\mathrm{ij}}=1,2, \ldots, 4\right)$, and $\varepsilon_{\mathrm{ij}}$ is the random residual error. The effects of light and glucose supplementation were considered fixed, and calf within treatment was included as a random effect. To determine time-dependent changes and interactions between time and treatment of effects with repeated measurements, the effects of treatments over time were evaluated using orthogonal contrasts. Birth weight was used as a covariate and effects were considered significant at a probability of $P<0.05$. Differences among treatment means were tested for significance using Tukey's multiple range test (v. 9.1, SAS Inst. Inc.). Data are expressed as mean \pm SEM, which represents the pooled SE for the model.

\section{RESULTS AND DISCUSSION}

\section{Intake and Weight Gain}

Initial and final calf weights, average daily and total gain, calf starter DMI, and water intake are presented in Table 2. All calves consumed the entire $2 \mathrm{~L}$ of milk offered twice daily. Glucose supplementation had no effect $(P>0.05)$ on starter intake and weight gains. The calves on LDPP were heavier $(P<0.05)$ at $d 56$ than SDPP calves regardless of level of glucose supple- 
Table 2. Effects of photoperiod and glucose supplementation in the drinking water on ADG and repeated measures of $\mathrm{BW}, \mathrm{ADG}$, and calf starter, water, and energy intake

\begin{tabular}{|c|c|c|c|c|c|c|c|c|}
\hline \multirow[b]{2}{*}{ Response $^{1}$} & \multicolumn{2}{|c|}{ No glucose } & \multicolumn{2}{|c|}{$50 \mathrm{~g}$ of glucose/L } & \multirow[b]{2}{*}{ SEM } & \multicolumn{3}{|c|}{ Time, $P$-value } \\
\hline & $\mathrm{SDPP}^{2}$ & $\mathrm{LDPP}^{3}$ & SDPP & LDPP & & Linear & Quadratic & Cubic \\
\hline $\mathrm{BW}, \mathrm{kg}$ & 58.0 & 62.2 & 57.6 & 58.5 & 2.41 & $<0.01$ & $<0.01$ & 0.21 \\
\hline Initial & 43.2 & 41.3 & 42.1 & 40.4 & 1.63 & - & - & - \\
\hline Final & $73.4^{\mathrm{a}}$ & $80.5^{\mathrm{b}}$ & $72.1^{\mathrm{a}}$ & $76.4^{\mathrm{b}}$ & 2.91 & - & - & - \\
\hline Gain & $30.2^{\mathrm{a}}$ & $39.2^{\mathrm{b}}$ & $30.0^{\mathrm{a}}$ & $36.0^{\mathrm{b}}$ & 3.27 & - & - & - \\
\hline ADG, g/d & 449.6 & 575.9 & 467.3 & 553.5 & 66.49 & $<0.01$ & 0.16 & 0.73 \\
\hline d 0 to 14 & 407.2 & 375.0 & 452.4 & 511.9 & 88.1 & - & - & - \\
\hline d 15 to 28 & 528.6 & 726.2 & 458.3 & 511.9 & 73.3 & - & - & - \\
\hline d 0 to 28 & 467.9 & 550.6 & 455.4 & 511.9 & 50.35 & - & - & - \\
\hline d 29 to 42 & $607.2^{\mathrm{a}}$ & $940.5^{\mathrm{b}}$ & $654.8^{\mathrm{a}}$ & $797.6^{\mathrm{b}}$ & 107.07 & - & - & - \\
\hline d 43 to 56 & $700.0^{\mathrm{a}}$ & $1,017.9^{\mathrm{b}}$ & $535.7^{\mathrm{c}}$ & $750.0^{\mathrm{d}}$ & 92.82 & - & - & - \\
\hline d 29 to 56 & $653.6^{\mathrm{a}}$ & $979.2^{\mathrm{b}}$ & $595.2^{\mathrm{a}}$ & $773.8^{\mathrm{b}}$ & 71.09 & - & - & - \\
\hline d 0 to 56 & $560.7^{\mathrm{a}}$ & $764.9^{\mathrm{b}}$ & $525.3^{\mathrm{a}}$ & $642.8^{\mathrm{b}}$ & 57.00 & - & - & - \\
\hline Starter intake, kg & $3.2^{\mathrm{a}}$ & $5.2^{\mathrm{b}}$ & $1.7^{\mathrm{c}}$ & $2.9^{\mathrm{a}}$ & 0.73 & $<0.01$ & 0.03 & 0.12 \\
\hline Water intake, L & 25.1 & 34.9 & 31.3 & 32.3 & 7.0 & $<0.01$ & $<0.01$ & $<0.01$ \\
\hline Energy intake, Mcal & 23.2 & 26.2 & 26.3 & 28.2 & 1.39 & $<0.01$ & 0.79 & 0.15 \\
\hline
\end{tabular}

${ }^{a-c}$ Values within rows with different superscript letters are significantly different $(P<0.05)$.

${ }^{1}$ Means of 6 calves per treatment.

${ }^{2} \mathrm{SDPP}=$ short-day photoperiod; $10 \mathrm{~h}$ of light.

${ }^{3} \mathrm{LDPP}=$ long-day photoperiod; $18 \mathrm{~h}$ of light.

mentation (Table 2). Repeated-measures analysis revealed that a quadratic equation adequately described the shape of the curve for weekly calf BW gain from birth to d 56. There were no differences $(P>0.05)$ in $\mathrm{ADG}$ from d 0 to 14 , ADG from d 15 to 28 , or the combined ADG from d 0 to 28 in agreement with Lesmeister and Heinrichs (2004), who also observed no treatment effects in DMI and ADG from d 0 to 28. This was not surprising because calves generally do not gain a significant amount of weight during the first 2 to 3 wk of life due to a variety of challenges including rumen development, health, environmental change, and nutrient intake (Toullec and Guilloteau, 1989; Davis and Drackley, 1998; Diaz et al., 2001).

The ADG of the calves on LDPP from d 29 to 42 and from d 43 to 56 and total gain were greater $(P<0.05)$ than those of calves on SDPP regardless of level of glucose supplementation. Tucker et al. (1984) showed that LDPP stimulated BW gain in heifers. The greater ADG of LDPP calves from d 29 to 56 was directly related to the greater $(P<0.05)$ calf starter DMI of these calves (Table 2). The effects of photoperiod on weight gain, calf starter DMI, and water intake of the calves from birth to 8 wk of age are presented in Figure 1. Calves on the LDPP consumed, on average, $78 \%$ more calf starter than SDPP calves. Calves need fermentable carbohydrates and fiber, which are found in calf starter to produce VFA for rumen epithelial development and for establishment of microbial populations (Harrison et al., 1960; Greenwood et al., 1997). In the current study, regression analysis of calf growth suggests that from birth to d 28, calf ADG was driven by milk intake.
However, by d $56,84 \%(P<0.05)$ of the variation in calf BW was explained by the amount of calf starter consumed. The best-fit linear model requiring minimal dietary information relating calf $\mathrm{BW}$ to calf starter energy intake was $[\mathrm{BW}(\mathrm{kg})=62.7( \pm 2.22)+1.33( \pm 0.186)$ calf starter energy intake (Mcal); $(\mathrm{n}=24$; residual $\mathrm{SD}=$ $\left.\left.1.02 ; \mathrm{R}^{2}=0.71 ; P<0.05\right)\right]$. There were no differences $(P>0.05)$ in water intake.

\section{Structural Growth}

Structural growth measurements of calves are presented in Table 3. Glucose supplementation had no effect $(P<0.05)$ on the structural growth measurements. Body widths through hooks of the calves on LDPP were greater $(P<0.05)$ than those of calves on SDPP regardless of level of glucose supplementation. Body widths through hooks were highly $(\mathrm{r}=0.72 ; P<0.001)$ correlated with BW, which in turn were related to calf starter DMI. The heart girth tape BW estimations were greater $(P<0.05)$ than those recorded on the electronic scale (88 vs. $59 \mathrm{~kg}$, respectively). This was in contrast to Dingwell et al. (2006), who reported that in the heifers aged $<3 \mathrm{mo}$, the heart girth tape measurements were lower than the scale measurements. The heart girth tape method has already been validated for older $(>3$ mo) heifers and is widely used (Heinrichs and Hargrove, 1987). There is a need to validate the relationship between the hipometer, heart girth, and BW in calves $<3$ mo of age. 



Figure 1. Effects of photoperiod on a) BW, b) calf starter DMI, and c) water intake of dairy calves from d 0 to 56 . The treatments were $10 \mathrm{~h}$ of light, $14 \mathrm{~h}$ of dark (short-day photoperiod, SDPP; — —) and $18 \mathrm{~h}$ of light, $6 \mathrm{~h}$ of dark (long-day photoperiod, LDPP; - - ).

\section{Rumen Parameters}

Ruminal ammonia, pH, osmolarity, acetate, propionate, butyrate, acetate-to-propionate ratio, and total VFA from d 29 to 56 are presented in Table 4. Glucose supplementation had no effects $(P<0.05)$ on rumen parameters. Calves exposed to LDPP had greater $(P<$ 0.05 ) ruminal osmolarity and greater concentrations of acetate, propionate, butyrate, and total VFA compared with SDPP calves at both levels of glucose supplementation, which suggests increased rumen epithelial metabolic activity in the LDPP calves. Ruminal osmolality normally ranges from 240 to $265 \mathrm{mOsm} / \mathrm{L}$ with roughage diets and 280 to $300 \mathrm{mOsm} / \mathrm{L}$ with concentrate diets (Garza et al., 1989). Consumption of calf starter is critical to the development of an active, functional 
Table 3. Effects of photoperiod and glucose supplementation in the drinking water on the repeated measures of structural growth measurements of dairy calves

\begin{tabular}{|c|c|c|c|c|c|c|c|}
\hline \multirow[b]{2}{*}{ Response $^{1}$} & \multicolumn{2}{|c|}{ No glucose } & \multicolumn{2}{|c|}{$50 \mathrm{~g}$ of glucose $/ \mathrm{L}$} & \multirow[b]{2}{*}{ SEM } & \multicolumn{2}{|c|}{ Time, $P$-value } \\
\hline & $\mathrm{SDPP}^{2}$ & $\mathrm{LDPP}^{3}$ & $\mathrm{SDPP}$ & LDPP & & Linear & Quadratic \\
\hline WW be & 88.5 & 89.5 & 88.1 & 89.1 & 1.01 & $<0.01$ & $<0.01$ \\
\hline Middle girth circumference, $\mathrm{cm}$ & 93.9 & 96.8 & 93.7 & 95.1 & 1.24 & $<0.01$ & $<0.01$ \\
\hline Height at withers, $\mathrm{cm}$ & 85.3 & 84.3 & 84.4 & 85.8 & 0.66 & $<0.01$ & $<0.01$ \\
\hline Height at rump, $\mathrm{cm}$ & 89.0 & 87.7 & 84.9 & 89.2 & 1.83 & $<0.01$ & 0.97 \\
\hline BW through hooks, cm & $19.8^{\mathrm{a}}$ & $20.1^{\mathrm{b}}$ & $19.9^{\mathrm{a}}$ & $21.0^{\mathrm{b}}$ & 0.28 & $<0.01$ & 0.05 \\
\hline
\end{tabular}

${ }^{\mathrm{a}, \mathrm{b}}$ Values within rows with different superscript letters are significantly different $(P<0.05)$.

${ }^{1}$ Means of 6 calves per treatment.

${ }^{2} \mathrm{SDPP}=$ short-day photoperiod; $10 \mathrm{~h}$ of light.

${ }^{3} \mathrm{LDPP}=$ long-day photoperiod; $18 \mathrm{~h}$ of light.

rumen. Butyrate and, to a lesser extent, propionate are used as energy sources by the rumen epithelium and subsequently have the greatest influence on epithelial development (Sander et al., 1959; Tamate et al., 1962). The LDPP calves had lower $(P<0.05)$ ruminal $\mathrm{pH}$ and lower $(P<0.05)$ acetate-to-propionate ratios compared with SDPP calves regardless of level of glucose supplementation (Table 4). This is supported by the greater $(P<0.05)$ concentrations of individual and total VFA in LDPP calves compared with SDPP calves (Table 4). This was not surprising because the LDPP calves also consumed $78 \%$ more $(P<0.05)$ calf starter DM during this period than SDPP calves. Rumen $\mathrm{pH}$ decreased linearly $(P<0.05)$ with time from d 29 to 56 in agreement with Beharka et al. (1998), who showed that ruminal $\mathrm{pH}$ was influenced by the age of the calf; that is, the $\mathrm{pH}$ declined after wk 2 and then increased at 10 wk of age. Anderson et al. (1987a,b) also reported a quadratic change in the relationship between $\mathrm{pH}$ and age of the calf. In the current study, rumen $\mathrm{pH}$ was only measured from d 29 to 56. In milk-fed calves, a condition known as "ruminal drinkers" (van Weeren-
Keverling, 1989) occurs when the esophageal (reticular) groove reflex is dysfunctional, allowing milk to spill into the reticulorumen instead of being delivered directly into the abomasum (Bruinessen-Kapsenberg et al., 1982; Dirr and Dirksen, 1989). Lactose and other easily fermentable carbohydrates contained in the milk or nutrient solution are fermented by the ruminal flora to form predominantly lactic acid plus other short-chain fatty acids (Gentile, 1995). As the organic acids accumulate in the rumen, the ruminal $\mathrm{pH}$ drops, which leads to acidosis (Gentile, 1995). In the current study, the acidosis was not sufficiently severe to alter health or performance. There were no differences $(P>0.05)$ in ammonia concentrations between treatments (Table 4).

\section{Serum Electrolytes and Metabolites}

Serum electrolytes and metabolites of the calves from d 0 to 56 are presented in Table 5. The concentrations of the serum electrolytes and metabolites are consistent with the biochemistry reference values for growing calves published by Lumsden et al. (1980) and Dubreuil

Table 4. Effects of photoperiod and glucose supplementation in the drinking water on the repeated measures of ruminal ammonia, $\mathrm{pH}$, osmolarity, acetate, propionate, butyrate, acetate-to-propionate ratio, and total VFA of neonatal dairy calves

\begin{tabular}{|c|c|c|c|c|c|c|c|c|}
\hline \multirow[b]{2}{*}{ Response $^{1}$} & \multicolumn{2}{|c|}{ No glucose } & \multicolumn{2}{|c|}{$50 \mathrm{~g}$ of glucose/L } & \multirow[b]{2}{*}{ SEM } & \multicolumn{3}{|c|}{ Time, $P$-value } \\
\hline & $\mathrm{SDPP}^{2}$ & $\mathrm{LDPP}^{3}$ & SDPP & LDPP & & Linear & Quadratic & Cubic \\
\hline Rumen $\mathrm{pH}$ & $6.24^{\mathrm{a}}$ & $5.78^{\mathrm{b}}$ & $6.30^{\mathrm{a}}$ & $5.68^{\mathrm{b}}$ & 0.160 & 0.01 & 0.29 & 0.70 \\
\hline Amm & 0.768 & 0.935 & 0.760 & 0.922 & 0.124 & 0.89 & 0.67 & 0.05 \\
\hline Osmolarity, $\mathrm{mmol} / \mathrm{L}$ & $257.0^{\mathrm{a}}$ & $326.7^{\mathrm{b}}$ & $259.8^{\mathrm{a}}$ & $304.3^{\mathrm{b}}$ & 18.43 & 0.72 & 0.59 & 0.01 \\
\hline Acetate $(\mathrm{A}), \mathrm{mmol} / \mathrm{L}$ & $33.7^{\mathrm{a}}$ & $43.1^{\mathrm{b}}$ & $31.2^{\mathrm{a}}$ & $39.0^{\mathrm{b}}$ & 3.53 & 0.26 & 0.23 & 0.17 \\
\hline Propionate $(\mathrm{P}), \mathrm{mmol} / \mathrm{L}$ & $15.5^{\mathrm{a}}$ & $28.3^{b}$ & $15.3^{\mathrm{a}}$ & $23.3^{\mathrm{b}}$ & 2.58 & 0.39 & 0.89 & 0.05 \\
\hline $\mathrm{A}: \mathrm{P}$ & $2.55^{\mathrm{a}}$ & $1.57^{\mathrm{b}}$ & $2.19^{\mathrm{a}}$ & $1.76^{\mathrm{b}}$ & 0.213 & 0.68 & 0.10 & 0.82 \\
\hline Butyı & $4.7^{\mathrm{a}}$ & $7.0^{\mathrm{b}}$ & $5.3^{\mathrm{a}}$ & $7.7^{\mathrm{b}}$ & 0.76 & 0.19 & 0.10 & 0.45 \\
\hline Total VFA, $\mathrm{mmol} / \mathrm{L}$ & $53.8^{\mathrm{a}}$ & $78.4^{\mathrm{b}}$ & $51.9^{\mathrm{a}}$ & $70.0^{\mathrm{b}}$ & 6.33 & 0.25 & 0.31 & 0.11 \\
\hline
\end{tabular}

${ }^{\mathrm{a}, \mathrm{b}}$ Values within rows with different superscript letters are significantly different $(P<0.05)$.

${ }^{1}$ Means of 6 calves per treatment.

${ }^{2} \mathrm{SDPP}=$ short-day photoperiod; $10 \mathrm{~h}$ of light.

${ }^{3} \mathrm{LDPP}=$ long-day photoperiod; $18 \mathrm{~h}$ of light. 
Table 5. Effects of photoperiod and glucose supplementation in the drinking water on the repeated measures of serum parameters of neonatal dairy calves

\begin{tabular}{|c|c|c|c|c|c|c|c|c|}
\hline \multirow[b]{2}{*}{ Response $^{1}$} & \multicolumn{2}{|c|}{ No glucose } & \multicolumn{2}{|c|}{$50 \mathrm{~g}$ of glucose/L } & \multirow[b]{2}{*}{ SEM } & \multicolumn{3}{|c|}{ Time, $P$-value } \\
\hline & $\mathrm{SDPP}^{2}$ & $\mathrm{LDPP}^{3}$ & SDPP & LDPP & & Linear & Quadratic & Cubic \\
\hline Glucose, $\mathrm{mmol} / \mathrm{L}$ & $6.70^{\mathrm{a}}$ & $6.46^{\mathrm{a}}$ & $7.26^{\mathrm{b}}$ & $7.06^{\mathrm{b}}$ & 0.252 & 0.09 & 0.61 & 0.21 \\
\hline NEFA, mEq/L & 0.135 & 0.168 & 0.156 & 0.135 & 0.017 & $<0.01$ & $<0.01$ & $<0.01$ \\
\hline Urea $\mathrm{N}, \mathrm{mmol} / \mathrm{L}$ & $4.26^{\mathrm{a}}$ & $4.22^{\mathrm{a}}$ & $3.33^{\mathrm{b}}$ & $3.13^{\mathrm{b}}$ & 0.262 & 0.89 & 0.01 & 0.08 \\
\hline Total protein, g/L & 62.3 & 60.6 & 58.0 & 59.4 & 3.66 & 0.09 & 0.92 & 0.17 \\
\hline $\mathrm{Ca}, \mathrm{mmol} / \mathrm{L}$ & 2.75 & 2.72 & 2.71 & 2.74 & 0.049 & $<0.01$ & $<0.01$ & 0.54 \\
\hline $\mathrm{P}, \mathrm{mmol} / \mathrm{L}$ & $2.71^{\mathrm{a}}$ & $2.77^{\mathrm{b}}$ & $2.77^{\mathrm{b}}$ & $2.98^{\mathrm{c}}$ & 0.064 & 0.04 & $<0.01$ & $<0.01$ \\
\hline $\mathrm{Mg}, \mathrm{mmol} / \mathrm{L}$ & 0.920 & 0.919 & 0.918 & 0.940 & 0.0341 & 0.27 & 0.33 & 0.87 \\
\hline $\mathrm{Na}, \mathrm{mmol} / \mathrm{L}$ & $143.3^{\mathrm{a}}$ & $143.6^{\mathrm{a}}$ & $144.5^{\mathrm{a}}$ & $149.0^{\mathrm{b}}$ & 1.40 & 0.13 & 0.70 & 0.85 \\
\hline $\mathrm{K}, \mathrm{mmol} / \mathrm{L}$ & 4.96 & 4.94 & 4.90 & 5.09 & 0.069 & $<0.01$ & 0.44 & 0.93 \\
\hline $\mathrm{Cl}, \mathrm{mmol} / \mathrm{L}$ & 101.3 & 101.1 & 101.5 & 105.1 & 1.31 & $<0.01$ & 0.11 & 0.89 \\
\hline Cholesterol, mmol/L & 2.73 & 2.67 & 2.14 & 2.59 & 0.180 & $<0.01$ & $<0.01$ & $<0.01$ \\
\hline $\mathrm{BHBA}, \mathrm{mmol} / \mathrm{L}$ & 246.2 & 228.8 & 222.3 & 218.0 & 21.8 & $<0.01$ & 0.48 & 0.14 \\
\hline $\mathrm{Na}: \mathrm{K}$ & 29.1 & 29.2 & 29.6 & 29.4 & 0.38 & $<0.01$ & 0.21 & 0.87 \\
\hline $\mathrm{Ca}: \mathrm{P}$ & $1.02^{\mathrm{a}}$ & $0.99^{b}$ & $0.99^{b}$ & $0.93^{c}$ & 0.227 & $<0.01$ & $<0.01$ & $<0.01$ \\
\hline
\end{tabular}

${ }^{\mathrm{a}-\mathrm{c}}$ Values within rows with different superscript letters are significantly different $(P<0.05)$.

${ }^{1}$ Means of 6 calves per treatment.

${ }^{2} \mathrm{SDPP}=$ short-day photoperiod; $10 \mathrm{~h}$ of light.

${ }^{3} \mathrm{LDPP}=$ long-day photoperiod; $18 \mathrm{~h}$ of light.

and Lapierre (1997). The concentration of serum glucose was greater for the calves supplemented with glucose, regardless of lighting regimen (Table 5). However, the concentrations of urea nitrogen for the calves supplemented with $50 \mathrm{~g}$ of glucose/L in the drinking water were lower $(P<0.05)$ than for the control calves regardless of lighting regimen. This finding is consistent with the results of Osborne et al. (2002), who reported that in transition cows, glucose supplementation in the drinking water improved the nitrogen status of the cows by reducing the rumen ammonia levels and blood urea, but did not alter the $\mathrm{NE}_{\mathrm{L}}$ balance during the peri-parturient period. In the current study, the glucose treatment also did not $(P>0.05)$ alter total energy intake (Table 2$)$.

The LDPP calves had greater $(P<0.05)$ concentrations of serum $\mathrm{P}$ and lower $(P<0.05)$ serum $\mathrm{Ca}$ : $\mathrm{P}$ ratios compared with the SDPP calves regardless of level of glucose supplementation. Several studies (Forar et al., 1982; Call et al., 1987; Wu et al., 2000) have shown that the concentration of $\mathrm{P}$ in serum is a reflection of $\mathrm{P}$ intake. During the first 2 to $3 \mathrm{wk}$ of life, the calf is essentially monogastric with a simple stomach, the abomasum, to digest milk components. As the calf consumes dry feed and water, the rumen begins to develop and becomes more important. The bioavailability of $\mathrm{P}$ in corn grain for young pigs was estimated to be less than $15 \%$ (NRC, 1998). About $70 \%$ of the total $\mathrm{P}$ is in the form of phytate or myo-inositol hexakisphosphate, a form that is unavailable to pigs (NRC, 1998). The greater concentrations of serum $\mathrm{P}$ for LDPP calves were probably due to increased availability of phytate $\mathrm{P}$ as a result of a more developed rumen, which encouraged greater intake of calf starter DM. Plasma P concentra- tion in growing cattle is normally in the range of 1.3 to $2.6 \mathrm{mmol} / \mathrm{L}$ (NRC, 2001).

\section{CONCLUSIONS}

Long-day photoperiods have been shown to increase milk production in lactating dairy cattle. The results of this study suggest that LDPP encouraged consumption of calf starter, which stimulated faster rumen development as evidenced by greater VFA concentrations and greater $\mathrm{ADG}$ in the calves but there was no direct evidence of rumen development per se. Glucose supplementation in the drinking water did not alter water intake. Photoperiod manipulation therefore offers a management tool that could enhance growth and accelerate the onset of puberty and therefore reduce the age of heifers at first parturition. Additional research is required to elucidate the metabolic mechanism.

\section{ACKNOWLEDGMENTS}

The authors thank the staff at the Elora Dairy Research Centre, University of Guelph, for their technical assistance, and the Dairy Farmers of Ontario, Ontario Ministry of Agriculture and Food, and the Natural Sciences and Engineering Research Council of Canada (BWM) for financial support.

\section{REFERENCES}

Anderson, K. L., T. G. Nagaraja, and J. L. Morrill. 1987a. Ruminal metabolic development in calves weaned conventionally or early. J. Dairy Sci. 70:1000-1005.

Anderson, K. L., T. G. Nagaraja, J. L. Morrill, T. B. Avery, S. J. Galitzer, and J. E. Boyer. 1987b. Ruminal microbial development 
in conventional or early-weaned calves. J. Anim. Sci. 64:12151226.

Beharka, A. A., T. G. Nagaraja, J. L. Morrill, G. A. Kennedy, and R. D. Klemm. 1998. Effects of form of the diet on anatomical, microbial and fermentative development of the rumen of neonatal calves. J. Dairy Sci. 81:1946-1955.

Bruinessen-Kapsenberg, E. G., T. van Wensing, and H. J. Breukink. 1982. Indigestionen der Mastkälber infolge fehlenden Schlundrinnenreflexes. Tierarztl. Umsch. 37:515-517.

Call, J. W., J. E. Butcher, J. L. Shupe, R. C. Lamb, R. L. Boman, and A. E. Olson. 1987. Clinical effects of low dietary phosphorous concentrations in feed given to lactating dairy cows. Am. J. Vet. Res. 48:133-136.

Dahl, G. E., B. A. Buchanan, and H. A. Tucker. 2000. Photoperiod effects on dairy cattle: A review. J. Dairy Sci. 83:885-893.

Dahl, G. E., T. H. Elsasser, A. V. Capuco, R. A. Erdman, and R. R. Peters. 1997. Effects of a long daily photoperiod on milk yield and circulating concentrations of insulin-like growth factor-I. J. Dairy Sci. 80:2784-2789.

Davis, C. L., and J. K. Drackley. 1998. The Development, Nutrition, and Management of the Young Calf. Iowa State University Press, Ames.

Diaz, M. C., M. E. Van Amburgh, J. M. Smith, J. M. Kelsey, and E. L. Hutten. 2001. Composition of growth of Holstein calves fed milk replacer from birth to 105 kilogram body weight. J. Dairy Sci. 84:830-842.

Dingwell, R. T., M. M. Wallace, C. J. McLaren, C. F. Leslie, and K. E. Leslie. 2006. An evaluation of two indirect methods of estimating body weight in Holstein calves and heifers. J. Dairy Sci. 89:3992-3998.

Dirr, L., and G. Dirksen. 1989. Oesophageal groove dysfunction as a complication of neonatal diarrhea in the calf. Bovine Pract. 24:53-60.

Dubreuil, P., and H. Lapierre. 1997. Biochemistry reference values for Québec lactating dairy cows, nursing sows, growing pigs and calves. Can. J. Vet. Res. 61:235-239.

Evans, N. M., and R. R. Hacker. 1989. Effect of chronobiological manipulation of lactation in the dairy cow. J. Dairy Sci. 72:2921-2927.

Flatt, W. P., R. G. Warner, and J. K. Loosli. 1958. Influence of purified materials on the development of the ruminant stomach. J. Dairy Sci. 41:1593-1600.

Forar, F. L., R. L. Kincaid, R. L. Preston, and J. K. Hillers. 1982. Variation of inorganic phosphorus in blood plasma and milk of lactating cows. J. Dairy Sci. 65:760-763.

Garza, J. D., F. N. Owens, and J. E. Breazile. 1989. Effects of diet on ruminal liquid and on blood serum osmolality and hematocrit in feedlot heifers. Okla. Agric. Exp. Stn. MP-127:68-76.

Geishauser, T. 1993. An instrument for the collection and transfer of ruminal fluid and for the administration of water-soluble drugs in adult cattle. Bovine Pract. 27:38-42.

Gentile, A. 1995. Untersuchungen über die Azidität der Pansenflüssigkeit von Kälbern nach intraruminaler Verabreichung von Rehydratationslösungen. Dtsch. Tierärztl. Wschr. 102:241-244.

Greenwood, R. H., J. L. Morrill, and E. C. Titgemeyer. 1997. Using dry feed intake as a percentage of initial body weight as a weaning criterion. J. Dairy Sci. 80:2542-2546.

Hansen, P. J., L. A. Kamwanja, and E. R. Hauser. 1983. Photoperiod influences age at puberty of heifers. J. Anim. Sci. 57:985-992.

Harrison, H. N., R. G. Warner, E. G. Sander, and J. K. Loosli. 1960. Changes in the tissue and volume of the stomachs of calves following the removal of dry feed or consumption of inert bulk. J. Dairy Sci. 43:1301-1312.

Heinrichs, A. J., and G. L. Hargrove. 1987. Standards of weight and height for Holstein heifers. J. Dairy Sci. 70:653-660.

Houpt, T. R. 1984. Water balance and excretion. In Duke's Physiology of Domestic Animals. 10th ed. M. J. Swenson, ed. Comstock Publishing Co., New York, NY.

Johnson, M. J., and J. P. Peters. 1993. Technical note: An improved method to quantify nonesterified fatty acids in bovine plasma. J. Anim. Sci. 71:753-756.
Kertz, A. F., L. F. Reutzel, and J. H. Mahoney. 1984. Ad libitum water intake by neonatal calves and its relationship to calf starter intake, weight gain, fecal score, and season. J. Dairy Sci. 76:2964-2969.

Leaver, J. D., and N. H. Yarrow. 1972. Rearing of dairy cattle. 2. Weaning calves according to their concentrate intake. Anim. Prod. 14:161-165.

Lesmeister, K. E., and A. J. Heinrichs. 2004. Effects of corn processing on growth characteristics, rumen development, and rumen parameters in neonatal dairy calves. J. Dairy Sci. 87:3439-3450.

Lumsden, J. H., K. Mullen, and R. Rowe. 1980. 1980. Hematology and biochemistry reference values for female Holstein cattle. Can. J. Comp. Med. 44:24-31.

Murphy, M. R. 1992. Water metabolism of dairy cattle. J. Dairy Sci. 75:326-333.

Nombekela, S. W., M. R. Murphy, H. W. Gonyou, and J. I. Marden. 1994. Dietary preferences in early lactation cows as affected by primary tastes and some common feed flavors. J. Dairy Sci. 77:2393-2399.

Novozamski, I., R. van Eck, J. C. van Schouwenburg, and I. Wallinga. 1974. Total nitrogen determination in plant material by means of the indophenol-blue method. Neth. J. Agric. Sci. 22:3-5.

NRC. 1998. Pages 110-123 in Nutrient Requirements of Swine. 10th rev. ed. Natl. Acad. Press, Washington, DC.

NRC. 2001. Nutrient Requirements of Dairy Cattle. 7th. rev. ed. National Acad. Sci. Washington, DC.

Osborne, V. R., K. E. Leslie, and B. W. McBride. 2002. Effect of supplementing glucose in drinking water on the energy and nitrogen status of the transition dairy cow. Can. J. Anim. Sci. 82:427-433.

Peters, R. R., L. T. Chapin, R. S. Emery, and H. A. Tucker. 1980. Growth and hormonal response to various photoperiods. J. Anim. Sci. 51:1148-1153.

Petitclerc, D., L. T. Chapin, R. S. Emery, and H. A. Tucker. 1983. Body growth, growth hormone, prolactin and puberty response to photoperiod and plane of nutrition in Holstein heifers. J. Anim. Sci. 57:892-898.

Petitclerc, D., R. D. Kineman, S. A. Zinn, and H. A. Tucker. 1985 Mammary growth response of Holstein heifers to photoperiod. J. Dairy Sci. 68:86-90.

Quigley, J. D., III, J. J. Drewry, L. M. Murray, and S. J. Ivey. 1997. Effects of lasalocid in milk replacer of calf starter on health and performance of calves challenged with Eimeria species. J. Dairy Sci. 80:2972-2976.

Rius, A. G., E. E. Connor, A. V. Capuco, P. E. Kendall, T. L. AuchtungMontgomery, and G. E. Dahl. 2005. 2005. Long-day photoperiod that enhances puberty does not limit body growth in Holstein heifers. J. Dairy Sci. 88:4356-4365.

Rius, A. G., and G. E. Dahl. 2006. Exposure to long-day photoperiod prepubertally may increase milk yield in first-lactation cows. J. Dairy Sci. 89:2080-2083.

Sander, E. G., R. G. Warner, H. N. Harrison, and J. K. Loosli. 1959. The stimulatory effect of sodium butyrate and sodium propionate on the development of rumen mucosa in the young calf. J. Dairy Sci. 42:1600-1605.

Schillo, K. K., J. B. Hall, and S. M. Hileman. 1992. Effects of nutrition and season on the onset of puberty in the beef heifer. J. Anim. Sci. 70:3994-4005

Schillo, K. K., P. J. Hansen, L. A. Kamwanja, D. J. Dierschke, and E. R. Hauser. 1983. Influence of season on sexual development in heifers: Age at puberty as related to growth and Plasma concentrations of gonadotropins, prolactin, thyroxine and progesterone. Biol. Reprod. 28:329-341.

Skidmore, A. 2001. Hipometer for estimation of body weight using the hip width measurement. Dairy Innovations, Alexander, NY.

Tamate, H., A. D. McGilliard, N. L. Jacobson, and R. Getty. 1962. Effect of various dietaries on the anatomical development of the stomach in the calf. J. Dairy Sci. 45:408-420.

Taylor, K. A. C. C. 1996. A simple colorimetric assay for muramic acid and lactic acid. Appl. Biochem. Biotechnol. 56:49-58. 
Thomas, L. C., T. C. Wright, A. Formusiak, J. P. Cant, and V. R. Osborne. 2007. Use of flavored drinking water in calves and lactating dairy cattle. J. Dairy Sci. 90:3831-3837.

Toullec, R., and P. Guilloteau. 1989. Research into the digestive physiology of the milk-fed calf. Pages 37-55 in Nutrition and Digestive Physiology in Monogastric Farm Animals. E. J. Van Weerdon and J. Huisman, ed. Pudoc, Wageningen, the Netherlands.

Tucker, H. A., D. Petitclerc, and S. A. Zinn. 1984. The influence of photoperiod on body weight gain, body composition, nutrient intake and hormone secretion. J. Anim. Sci. 59:1610-1620.

Van Soest, P. J., J. B. Robertson, and B. A. Lewis. 1991. Methods for dietary fiber, neutral detergent fiber, and non-starch polysac- charides in relation to animal nutrition. J. Dairy Sci. 74:35833597.

van Weeren-Keverling, B. A. 1989. Ruminal drinking in veal calves. Proefschrift, Utrecht, the Netherlands.

Waldo, D. R., and L. H. Schultz. 1960. Blood and rumen changes following the intra-ruminal administration of glycogenic materials. J. Dairy Sci. 43:496-505.

Williamson, D. H., J. Mellanby, and H. A. Krebs. 1962. Enzymatic determination of $\mathrm{D}(-) \beta$-hydroxybutyrate and acetoacetic acid in blood. Biochem. J. 82:90-96.

Wu, Z., L. D. Satter, and R. Sojo. 2000. Milk production, reproductive performance, and fecal excretion of phosphorus by dairy cows fed three amounts of phosphorus. J. Dairy Sci. 83:1028-1041. 